\title{
In the Heart of the Amazon: Noncommunicable Diseases and Apolipoprotein E4 Genotype in the Riverine Population
}

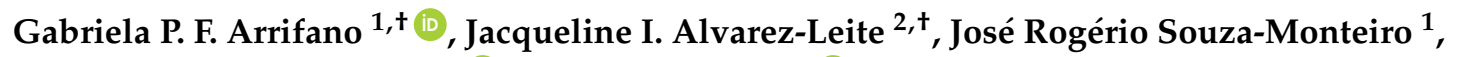 \\ Marcus Augusto-Oliveira ${ }^{3,+}$ (D) , Ricardo Paraense ${ }^{1}$ (D), Barbarella M. Macchi ${ }^{4}$, André Pinto ${ }^{5}$, \\ Reinaldo B. Oriá ${ }^{6}$, José Luiz Martins do Nascimento ${ }^{4}$ and Maria Elena Crespo-Lopez ${ }^{1, *}$ (i) \\ 1 Laboratório de Farmacologia Molecular, Instituto de Ciências Biológicas, Universidade Federal do Pará, \\ Belém 66075-110, Brazil; gabrielaarrifano@uol.com.br (G.P.F.A.); \\ rogerio.souza.monteiro@gmail.com (J.R.S.-M.); pos_ricardo@hotmail.com (R.P.) \\ 2 Departamento de Bioquímica e Imunologia, Universidade Federal de Minas Gerais, \\ Belo Horizonte 31270-90, Brazil; jalvarezleite@gmail.com \\ 3 Laboratório de Investigações em Neurodegeneração e Infecção (Hospital Universitário João de \\ Barros Barreto), Universidade Federal do Pará, Belém 66063-023, Brazil; marcusoliveira@globo.com \\ 4 Laboratório de Neuroquímica e Biologia Celular, Instituto de Ciências Biológicas, \\ Universidade Federal do Pará, Belém 66075-110, Brazil; barbarella@ufpa.br (B.M.M.); \\ jlmn@ufpa.br (J.L.M.d.N.) \\ 5 Laboratório de Análises Clínicas, Instituto de Ciências Biológicas, Universidade Federal do Pará, \\ Belém 66075-110, Brazil; andremontep1@hotmail.com \\ 6 Laboratório da Biologia da Cicatrização, Ontogenia e Nutrição de Tecidos, Departamento de Morfologia e \\ Instituto de Biomedicina, Escola de Medicina, Universidade Federal do Ceará, Fortaleza 60430-160, Brazil; \\ oria@ufc.br \\ * Correspondence: maria.elena.crespo.lopez@gmail.com; Tel.: +55-91-3201-8212 \\ + These authors had equal contribution.
}

Received: 5 July 2018; Accepted: 7 August 2018; Published: 7 September 2018

Abstract: The Amazon River basin is the largest tropical forest in the world. Most of the Amazon belongs to Brazil, a developing country that currently faces huge challenges related to the consolidation of its universal healthcare system. Noncommunicable diseases (NCDs) are the leading cause of death in Brazil, accounting for $74 \%$ of all deaths, and NCDs are probably underestimated in Amazonian population because of their geographical isolation and the precariousness of riverine communities. Important risk factors, such as genetic susceptibility, remain undetermined in the riverine population. This study performed fasting blood sugar (FBS) and blood pressure measurements and investigated the presence of the $\varepsilon 4$ allele of apolipoprotein E (APOE4) to determine the prevalence of diabetes, hypertension and the genetic risk of NCDs. FBS and APOE4 were measured in blood samples from 763 participants using spectrometry and real-time PCR; $67.5 \%$ showed altered measurements, and $57.9 \%$ had never been diagnosed or treated. Altered FBS was found in $28.3 \%$ of the participants, hypertension in $57.6 \%$ and APOE4 in $32.0 \%$. The health profile of the riverine population appears to differ from that of urban population in the Amazon. Additional risk factors for NCDs, such as environmental contamination and nutritional transition, may contribute more than increased genetic susceptibility to the prevalence of altered FBS and hypertension. Our results will help guide the development of preventive strategies and governmental actions for more effective management of NCDs in the Amazon area.

Keywords: Amazon; hypertension; diabetes; noncommunicable diseases; apolipoprotein; apoE; genotyping; riverine; Tapajos; Tucurui 


\section{Introduction}

The Amazon River basin is the largest tropical forest in the world and is home to more than 17 million people [1]. Most of the Amazon belongs to Brazil, a developing country with an emerging economy that faces huge challenges related to the consolidation of its universal healthcare system [2]. The disparities between the richest $10 \%$ and the poorest $10 \%$ of the Brazilian population have grown in recent decades [2], and the Northern region has the lowest Human Development Index [3].

In the Amazon, a large part of the population lives far from major cities in small riverine communities or in widespread family-based houses. The Amazonian riverine population is mixed-ethnicity (Indigenous/Amerindian/Portuguese/African) [4], and the Amazon river is a central element in the lifestyle of the population. Fish are the main source of protein in the diet and are usually consumed in more than seven meals per week. Water from the river or from hand-dug wells is used for cooking, and there is a risk of water contamination by garbage that is burned, buried, or dumped directly into the river. Conditions are not always sanitary, as there is no electricity or sewage system, and the population has little or no access to medical facilities. Most of the population goes to school for eight years or less. Although a wide variety of fruits are available and are widely consumed [5], dietary factors such as the nutrition transition [5,6] may be contributing to an increase in the prevalence of noncommunicable diseases (NCDs) in these communities. The area's geographical isolation and poor access to healthcare make it difficult to routinely collect epidemiological data about health problems such as NCDs in these communities.

The most prevalent NCDs are cardiovascular diseases (CVDs), chronic respiratory diseases, diabetes mellitus (DM), and cancer. NCDs cause approximately 40 million deaths worldwide annually and are one of the major health and development challenges of the 21st century [7]. About $80 \%$ of all premature deaths (30-69 years) in the world due to NCDs occur in low- and middle-income countries [7], most of them related to cardiovascular conditions.

Determining the presence of the $\varepsilon 4$ allele of apolipoprotein E (APOE4 for the gene; ApoE4 for the protein) is important for evaluating the risk of NCDs [8-10]. Apolipoprotein E (ApoE) is a 299-amino acid, 34-kD glycoprotein that plays an essential role in the regulation of lipid metabolism and in cholesterol transport [11,12]. Humans have three major isoforms of this apolipoprotein due to single nucleotide polymorphisms at positions 112 and 158: ApoE2 (Cys112/Cys158), ApoE3 (Cys112/Arg158), and ApoE4 (Arg112/Arg158). These minor differences in the primary structures of the ApoE isoforms have major effects on both its secondary structure and its function. APOE4 is a recognized genetic risk factor for CVDs and for age-related NCDs, especially neurodegenerative NCDs such as dementia. Recent works in humans found associations between ApoE4 and diverse NCDs, such as DM, dyslipidemias, and thrombosis $[8,9,13,14]$. Animal studies have established some of the molecular mechanisms underlying these associations. For example, ApoE4 may confer a proatherogenic profile by impairing VLDL clearance because ApoE4 has a greater lipid and VLDL-binding ability than ApoE3 [15]. ApoE4 may also impair insulin signaling in the brain, probably because its direct binding to the insulin receptor may trap it in endosomes preventing it from interacting with insulin [16].

In Brazil, NCDs are the leading cause of death, accounting for $74 \%$ of all deaths in the country $[17,18]$. The prevalence of chronic diseases, including hypertension and DM, is worryingly high-for example, Brazil is currently ranked as the fourth country in the world in terms of the number of patients with DM $[19,20]$. The most recent data indicates that the prevalence of medical diagnosis of hypertension and DM have increased 3.5\% and 2.8\%, respectively, in the last decade [18]. However, in some regions, such as the Amazon River basin, the prevalence of NCDs is probably underestimated due to geographical isolation and the precariousness of healthcare for people living in the riverine communities. Thus, the Amazon area represents a huge healthcare challenge. In addition, the prevalence of important risk factors, such as those associated with possible genetic susceptibility, is not totally known in these populations. 
Given this context, we investigated fasting blood sugar (FBS) levels, blood pressure, and the presence of ApoE4 in Amazonian riverine population in order to determine the prevalence of DM and hypertension and to evaluate the risk of NCDs.

\section{Materials and Methods}

\subsection{Ethics}

This project followed the guidelines of the Declaration of Helsinki and was approved by the National Council for Ethics in Research (CONEP, Brazil; CAAE No. 43927115.4.0000.0018). The participants were informed about the aim of the study prior to their inclusion and provided written consent for participation in the study.

\subsection{Study Population and Inclusion/Exclusion Criteria}

The Amazonian population in this study was from the State of Pará, Brazilian Amazon (Figure 1). Two regions were included that represented the two most common social structures found in Amazonian riverine populations: the Tapajós River basin $(-4.287121,-55.984106)$, which comprises small communities that live alongside the river; and Tucuruí Lake $(-3.800897,-49.811848)$ in which the riverine inhabitants live on islands, with a few families on each island.

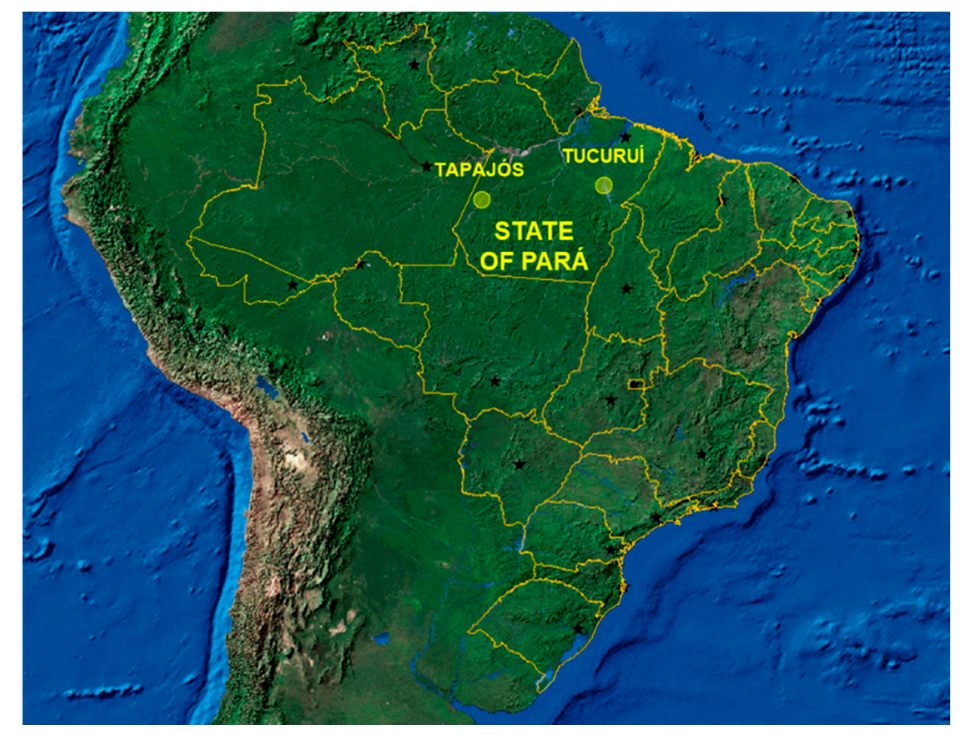

Figure 1. Map of the States of Brazil (yellow lines) and their capitals (black stars) obtained from the Instituto Brasileiro de Geografía e Estatística (IBGE, Brazil). The State of Pará and the approximate locations of the two regions (Tapajós and Tucuruí) are identified.

This project was publicized via radio, meetings, and direct communications with healthcare agents. Samples were collected from volunteer participants at community meeting places such as schools. The inclusion criteria included adults $\geq 18$ years old living in Amazonian riverine communities for at least two years. Participants without venous access, who registered twice, or who refused to donate blood were excluded. The first statistical analysis was performed using these inclusion/exclusion criteria (Analysis $1-\mathrm{NCDs}$ in the total population).

Additionally, to better study the 'presumably healthy' population, a second statistical analysis (Analysis 2-NCDs in the 'presumably healthy' population) was performed to evaluate a subgroup of participants that was created a posteriori by using additional exclusion criteria: $>65$ years old; a history or previous diagnosis of an NCD; drug dependency, including tobacco and alcohol; and chronic treatment with drugs. 
The APOE4 genotype risk factor was analyzed statistically for the total population and for the subgroup of 'presumably healthy' participants (Analysis 3-Genetic risk factor (APOE4) for NCDs).

\subsection{Sample and Data Collection}

Data collection was performed from 2015 to 2017. A questionnaire was administered to each participant by personnel that were trained to register data related to health conditions, including the presence of pre-existing chronic diseases (such as CVDs, hypertension or DM), drug dependency (including tobacco and alcohol), and chronic treatments with drugs.

To quantify supine systolic and diastolic blood pressure (SBP and DBP, respectively), at least two measures were performed in the left arm separated by a 10-min rest interval, and then the mean was calculated. An approximately $3 \mathrm{~mL}$ of fasting blood sample was collected by venipuncture: $2 \mathrm{~mL}$ were collected into a vacutainer EDTA tube and immediately frozen and stored until the isolation of genomic DNA, and $1 \mathrm{~mL}$ was collected into a BD Vacutainer SST II Advance ${ }^{\circledR}$ tube, which was immediately processed for FBS determination. Serum was separated by centrifugation of the 1-mL sample, and FBS was assayed with a commercial kit (Labtest, Belém, Brazil).

\subsection{Detection of the Apolipoprotein E4 Genotype (APOE4)}

Genomic DNA was isolated from the frozen blood samples using the Purelink Genomic DNA Mini Kit (ThermoFisher, São Paulo, Brazil), according to the manufacturer's instructions. The presence of APOE4 was detected by real time-PCR using TaqMan ${ }^{\circledR}$ assays (ThermoFisher, São Paulo, Brazil) using StepOnePlus ${ }^{\circledR}$ equipment (ThermoFisher, São Paulo, Brazil). Two APOE single-nucleotide polymorphisms (SNPs), rs429358 and rs7412, were analyzed as described elsewhere [4]. All materials, including primers and probes, were obtained from ThermoFisher (São Paulo, Brazil). The reactions were carried out in 96-well microtiter plates. The assay volume was $10 \mu \mathrm{L}: 5 \mu \mathrm{L}$ of 2 X TaqMan Universal PCR Master Mix (ThermoFisher, São Paulo, Brazil), $25 \mathrm{nmol} / \mathrm{L}$ of each probe (FAM or VIC-labeled), and $0.5 \mu \mathrm{L}$ of DNA (30-100 ng). Reactions were performed in duplicate with 40 cycles of denaturation at $92{ }^{\circ} \mathrm{C}$ for $15 \mathrm{~s}$ and hybridization and extension at $60{ }^{\circ} \mathrm{C}$ for $1 \mathrm{~min}$.

\subsection{Statistical Analysis}

Statistical analysis was performed using GraphPad Prism 6 software (available at: www.graphpad.com). The Gaussian distribution of the data was analyzed using the D'Agostino-Pearson omnibus normality test. Nonparametric data are reported as medians and interquartile ranges, and the Mann-Whitney $U$ test was used to detect differences between two groups. Frequencies were analyzed with Fisher's exact test, the Chi-square test, and binomial test. Hardy-Weinberg equilibrium was tested to verify polymorphisms in APOE gene. For all analyses, $p<0.05$ was considered statistically significant.

\section{Results}

\subsection{Analysis $1-N C D$ s in the Total Population}

A total of 857 people registered for our study, 94 of whom were excluded because they did not have venous access, participated twice, or refused to donate blood. Complete data were available for 763 adult participants (487 women and 276 men). The participants' demographic and clinical characteristics are reported in Table 1.

The median BMI was $26.0 \mathrm{~kg} / \mathrm{m}^{2}$, ranging from 16.6 to $48.6 \mathrm{~kg} / \mathrm{m}^{2}$ (Table 1). Women had higher BMI than men. The median FBS was $90 \mathrm{mg} / \mathrm{dL}$, ranging from 32 to $359 \mathrm{mg} / \mathrm{dL}$; the median SBP was $125 \mathrm{mmHg}$, ranging from 70 to $239 \mathrm{mmHg}$; and the median DBP was $79 \mathrm{mmHg}$, ranging from 44 to $131 \mathrm{mmHg}$ (Table 1). Men had higher SBP and DBP values than women, but there were no significant differences in FBS levels according to sex (Table 1). 
Table 1. Demographic and clinical characteristics of the Amazonian riverine population that participated in this study. Data are presented as medians and interquartile intervals. Differences between sexes were analyzed by a binomial test for the number of participants and by the Mann-Whitney U test for the other parameters. The $p$-values are shown.

\begin{tabular}{|c|c|c|c|c|}
\hline \multirow{2}{*}{ Characteristics } & \multirow{2}{*}{ Total } & \multicolumn{2}{|c|}{ Sex } & \multirow{2}{*}{$\begin{array}{c}\text { Gender Difference } \\
p \text {-Value }\end{array}$} \\
\hline & & Women & Men & \\
\hline Subjects, $n(\%)$ & $763(100.0)$ & 487 (63.8) & $276(36.2)$ & $<0.0001^{\mathrm{a}}$ \\
\hline Age, years & $47(34-57)$ & $44(31-55)$ & $51(40-62)$ & $<0.0001^{b}$ \\
\hline Height, cm & $155(151-162)$ & $152(148-156)$ & $164(158-169)$ & $<0.0001^{b}$ \\
\hline Weight, kg & $64.3(56.0-74.6)$ & $61.7(53.7-71.0)$ & $69.3(60.1-78.3)$ & $<0.0001^{b}$ \\
\hline BMI, kg/m² & $26.0(23.3-29.6)$ & $26.7(23.3-30.4)$ & $25.5(23.3-28.5)$ & $0.0032^{b}$ \\
\hline FBS, mg/dL & $90(81-103)$ & $90(81-106)$ & $90(80-100)$ & $\mathrm{ns}^{\mathrm{b}}$ \\
\hline SBP, mmHg & 125 (113-139) & $121(110-137)$ & $129(120-142)$ & $<0.0001^{b}$ \\
\hline $\mathrm{DBP}, \mathrm{mmHg}$ & $79(70-88)$ & $77(69-86)$ & $80(73-89)$ & $<0.0001^{b}$ \\
\hline
\end{tabular}

Note: BMI, body mass index (calculated as weight in kilograms divided by the square of height in meters). FBS, fasting blood sugar; SBP, systolic blood pressure; DBP, diastolic blood pressure; ns, non-significant.

a Binomial test; ${ }^{\mathrm{b}}$ Mann-Whitney $U$ test.

The American Diabetes Association (2016) guidelines [21] were used to determine which participants had altered FBS: $100-125 \mathrm{mg} / \mathrm{dL}$ was considered impaired glucose tolerance and $\geq 126 \mathrm{mg} / \mathrm{dL}$ was considered DM. Because a DM diagnosis requires at least two measures of FBS $\geq 126 \mathrm{mg} / \mathrm{dL}$, patients with a single measure of FBS $\geq 126 \mathrm{mg} / \mathrm{dL}$ were categorized as "DM-suspected". The American College of Cardiology and the American Heart Association (ACC/AHA) guidelines [22] were used to identify individuals with altered blood pressure, so systemic arterial hypertension (SAH) was defined as SBP $\geq 130 \mathrm{mmHg}$ and/or DPB $\geq 80 \mathrm{mmHg}$.

Surprisingly, 515 participants (67.5\% (95\% confidence interval, CI: 64.0-70.8)) showed altered FBS (impaired glucose tolerance or DM-suspected) and/or SAH. Indeed, 134 individuals (17.8\%; CI: 15.1-20.7) had both SAH and altered FBS. The prevalence of DM-suspected was 10.7\% (CI: 8.1-13.8) in women; this was significantly higher than in men (5.4\%; CI: 3.1-8.8) (Fisher's exact test, $p<0.05$ ) (Figure 2). In both women and men, the prevalence of hypertension (systolic or diastolic) was significantly higher than that of altered FBS (Fisher's exact test, $p<0.0001$ ) (Figure 2). However, men more frequently had SAH (66.5\%; CI: 60.6-72.1) than women (52.6\%; CI: 48.0-57.2) (Fisher's exact test, $p<0.001$ ) (Figure 2).

\subsection{Analysis 2-NCDs in the 'Presumably Healthy' Sub-Group}

We used additional exclusion criteria to identify and analyze a 'presumably healthy' population. This was a subgroup of participants who were 18-65 years old with no history or previous diagnosis of NCDs, drug dependency, or chronic treatment with drugs. This subgroup $(n=513)$ was younger and showed median values of all parameters slightly lower than the total population (Figure 3 ). Surprisingly, a high proportion ( $58.1 \%$; CI: $53.7-62.4 ; n=298)$ of participants of this 'presumably healthy' subgroup had values above the reference limits despite the inclusion/exclusion criteria. Specifically, the prevalence of altered FBS was $26.5 \%$ (CI: 22.7-30.6) and the prevalence of SAH (systolic and / or diastolic) was $45.2 \%$ (CI: 40.8-49.6) (Figure 3). 

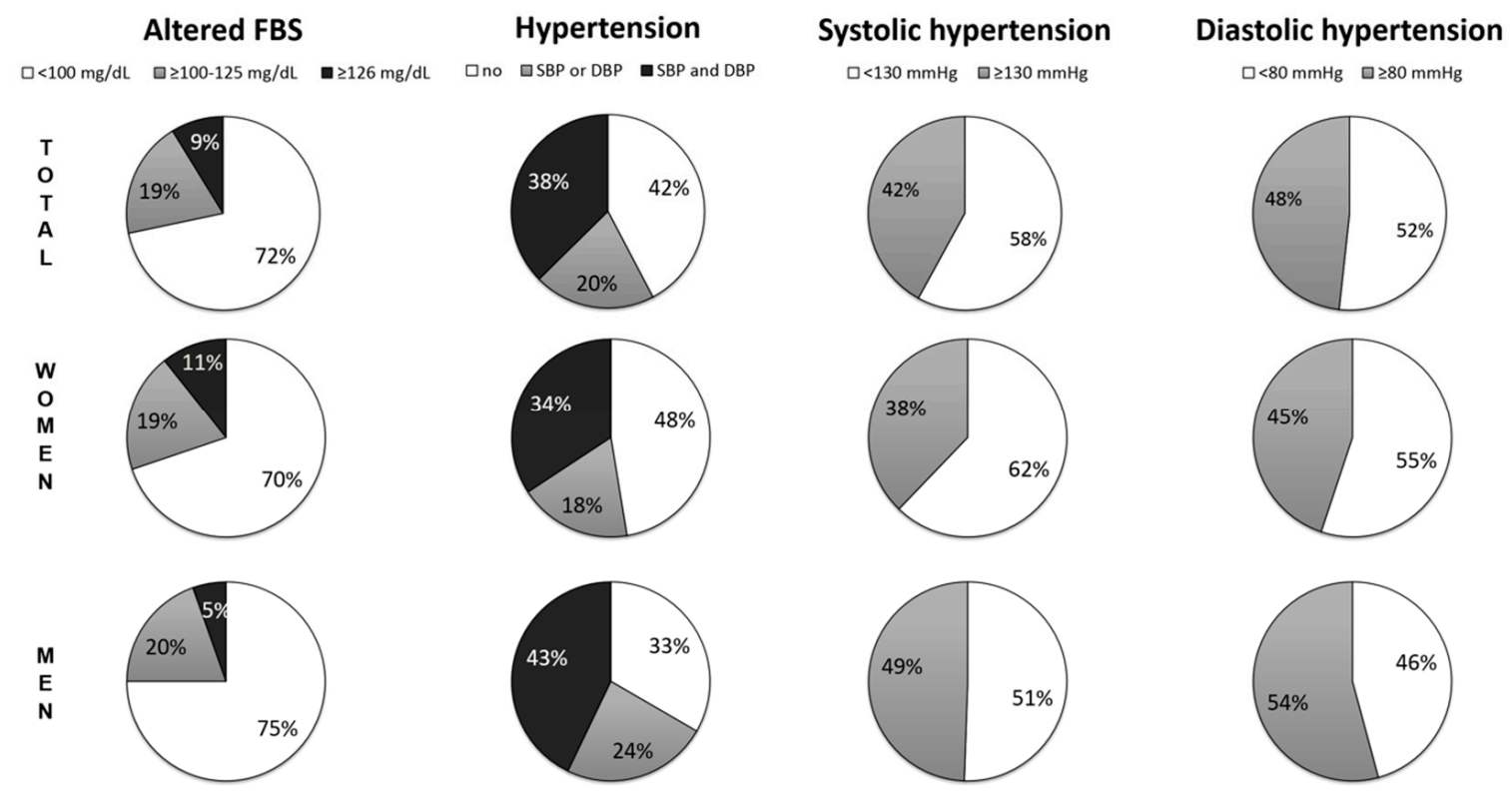

Figure 2. The prevalence of altered fasting blood sugar (FBS), hypertension, systolic hypertension or diastolic hypertension in the total population (first line), in women (second line), and in men (third line). According to the American Diabetes Association (2016) [21], impaired glucose tolerance was defined as FBS $\geq 100-125 \mathrm{mg} / \mathrm{dL}$ (gray) and diabetes mellitus (DM)-suspected was defined as $\geq 126 \mathrm{mg} / \mathrm{dL}$ (black). Systolic hypertension was defined as blood pressure $\geq 130 \mathrm{mmHg}$ and diastolic hypertension as blood pressure $\geq 80 \mathrm{mmHg}$.

\subsection{Analysis 3-Genetic Risk Factor (APOE4) for NCDs}

A substantial number of participants carried the $\varepsilon 4$ allele of the APOE gene (Figure 4), and many already showed alterations. Data from the total population was in Hardy-Weinberg equilibrium $\left(\chi^{2}=0.3625\right)$. The most frequent APOE genotypes were $\varepsilon 3 / \varepsilon 3(59.5 \%)$ and $\varepsilon 3 / \varepsilon 4(26.5 \%)$. The allelic frequencies were $0.05,0.77$, and 0.18 for the $\varepsilon 2, \varepsilon 3$ and $\varepsilon 4$ alleles, respectively. The proportion of participants with high FBS $(\geq 100 \mathrm{mg} / \mathrm{dL})$ and/or SAH was similar for the $\varepsilon 4$ carriers $(65.0 \%$; CI: 58.7-71.0) and the non- $\varepsilon 4$ carriers (68.7\%; CI: 64.5-72.6) (Fisher's exact test, $p>0.05)$. Notably, 166 individuals (32.4\%; CI: 28.3-36.6) in the 'presumably healthy' subgroup were $\varepsilon 4$ carriers, while 100 individuals who were $\varepsilon 4$ carriers $(60.2 \%$; CI: 52.4-67.7) in the 'presumably healthy' subgroup had altered FBS $(\geq 100 \mathrm{mg} / \mathrm{dL})$ and/or SAH. 


\begin{tabular}{|cc|}
\hline \multicolumn{2}{c}{ Presumably Healthy } \\
\hline Subjects, $n$ & 513 \\
Age, years & $41(30-50)$ \\
FBS, $\mathrm{mg} / \mathrm{dl}$ & $89(79-101)$ \\
SBP, $\mathrm{mmHg}$ & $120(110-133)$ \\
DBP, $\mathrm{mmHg}$ & $78(70-85)$ \\
\hline
\end{tabular}

Altered FBS

$\square<100 \mathrm{mg} / \mathrm{dL} \quad \square \geq 100-125 \mathrm{mg} / \mathrm{dL} \quad \square \geq 126 \mathrm{mg} / \mathrm{dL}$

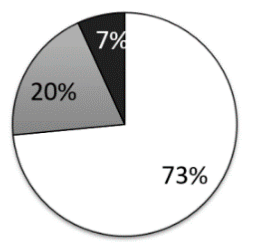

Hypertension

$\square$ no $\square$ SBP or DBP $\square$ SBP and DBP

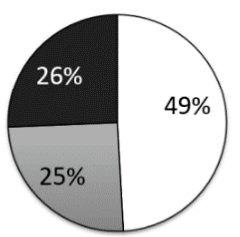

Systolic hypertension

$\square<130 \mathrm{mmHg} \quad \square \geq 130 \mathrm{mmHg}$

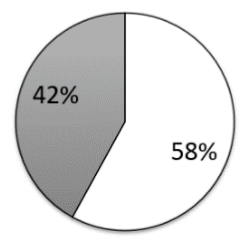

\section{Diastolic hypertension}

$\square<80 \mathrm{mmHg} \quad \square \geq 80 \mathrm{mmHg}$

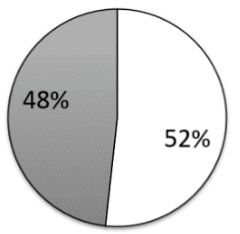

Figure 3. The prevalence of altered fasting blood sugar (FBS) levels, systolic hypertension, and diastolic hypertension in the presumably healthy subgroup. The presumably healthy subgroup was defined as participants who were 18-65 years old with no history or previous diagnosis of NCDs, drug dependency, or chronic treatment with drugs. According to the American Diabetes Association (2016) [21], impaired glucose tolerance was defined as FBS $\geq 100-125 \mathrm{mg} / \mathrm{dL}$ (gray) and diabetes mellitus (DM)-suspected was defined as $\geq 126 \mathrm{mg} / \mathrm{dL}$ (black). Systolic hypertension was defined as blood pressure $\geq 130 \mathrm{mmHg}$ and diastolic hypertension as blood pressure $\geq 80 \mathrm{mmHg}$. Data are presented as medians and interquartile ranges (table) and as proportions of participants (graphs). 
Total Population $n=763$

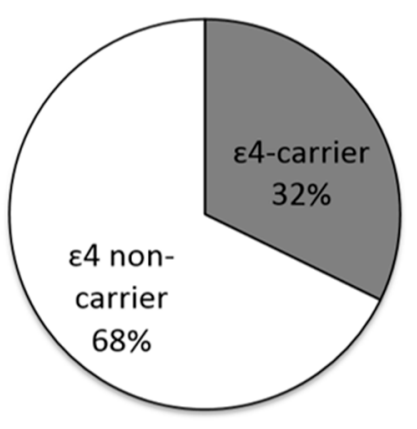

$\varepsilon 4$-carriers

$n=246$

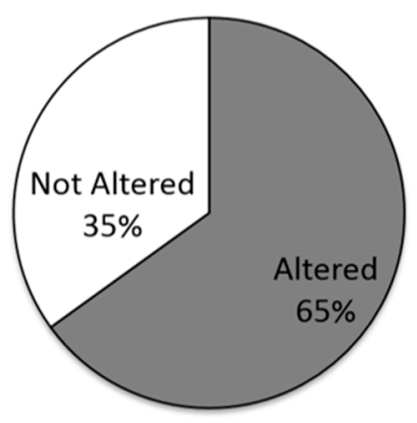

Figure 4. The distribution of APOE4 in the total population. The percentage of $€ 4$ carriers in the total population (left, gray) and the proportion of $\epsilon 4$ carriers showing altered fasting blood sugar ( $\geq 100 \mathrm{mg} / \mathrm{dL}$ ) and/or systemic arterial hypertension (right, gray).

\section{Discussion}

This study is the first to evaluate the prevalence of two NCDs and a genetic risk factor in Amazonian riverine population. It found a high prevalence of altered FBS (impaired glucose tolerance or DM-suspected) and/or SAH. More than half of the individuals with altered FBS and/or SAH did not have a previous diagnosis and were not being treated. In addition, a high proportion of the participants were $\varepsilon 4$ carriers, and $65.0 \%$ of these individuals already had altered FBS and/or hypertension.

Age-adjusted NCD mortality has fallen by $1.8 \%$ per year since the implementation of policies to prevent NCDs in Brazil [23]. However, the NCDs like CVDs continue to have deleterious consequences. Recent data indicate that although the mortality rate of some CVDs, such as heart ischemia, seem to be steady in Brazil, this is due to a decrease in the number of deaths due to cardiovascular causes in the south and southeast regions that is balanced by significant increases in deaths in the northern-northeastern region [24]. Between 2000 and 2010, the number of deaths increased by $28 \%$ in the northern region, but decreased by $13 \%$ to $25 \%$ in the southern-southeastern regions. We hypothesize that this significant increase in the northern region is underestimated because the communities are typically isolated, leading to underreporting of NCDs. Two observations support our hypothesis. First, Amazonian cities report a low prevalence of SAH and diabetes-indeed, the reported prevalence of these conditions is among the lowest in all Brazilian capital cities [18]. Second, our data showed that the prevalence in riverine population was as high as the prevalence in São Paulo and Rio de Janeiro, the largest cities in the country.

This study included 763 participants (Table 1), it was similar in size or larger than published studies that have looked at the characteristics of the Amazonian riverine population [25-35].

In Brazil, the probability of dying between 30 and 70 years of age because of an NCD is $19 \%$ [17]. The median age of the population in our study was 47 years, with 575 individuals $(75.4 \%$; $72.1-78.4$ ) between 30 and 70 years of age. Surprisingly, 71.3\% (CI: 67.4-75.0) of these 575 individuals had FBS $\geq 100 \mathrm{mg} / \mathrm{dL}$ and/or hypertension. These data suggest that there is an urgent need for interventions in these populations. According to the WHO (2014) [17], four main NCD risk factors are modifiable: unhealthy diets, physical inactivity, tobacco use, and the harmful use of alcohol. Eliminating these risk factors could prevent $80 \%$ of all cases of heart disease, stroke, and type 2 diabetes and more than $40 \%$ of cases of cancer [17].

Diabetes diagnosis in Brazilian capitals increased from 5.5\% to $7.4 \%$ in the last 10 years [18]. Interestingly, educational level has been associated with diabetes prevalence, with individuals with 0-8 years of formal education having a more than three-fold higher prevalence (13.5\%) compared to those with $>8$ years of education (4.4\%) [18]. Educational level might also be associated with a higher 
prevalence of diabetes in isolated Amazonian populations, such as those in riverine communities (Figure 2), who traditionally have a low educational level.

Impaired glucose tolerance is a major risk factor for type 2 diabetes [9], so the high number of participants in our study with impaired glucose tolerance $(n=149 ; 19 \%)$ is a serious concern (Figure 2). If these individuals do not change their habits and if they continue to be inadequately treated, they could develop type 2 diabetes in the near future. Strikingly, in addition to the $9 \%$ of individuals that were classified as DM-suspected, this means that as many as $28 \%$ of the riverine population could develop DM in the future. DM can result in irreversible visual impairment (i.e., blindness), in the amputation of extremities, and it can lead to premature retirement. Thus, the prevalence could exceed the current prevalence of DM in urban populations of the Amazon [18,33].

The difference in the number of women and men who participated in our study was expected, since this imbalance is common in epidemiological studies of Amazonian populations [35,36]. Women in these communities seem to be more careful with their healthcare than men, leading to this imbalance [37]. The role that male versus female sex plays in the prevalence of NCDs is still a matter of debate. Many studies support the notion that the prevalence of NCDs differs according to sex $[38,39]$. A survey of subjects in middle- and low-income countries reported that male sex is a risk factor for NCDs [40]. Interestingly, recent data from a large cohort of subjects in the Taiwanese military support this hypothesis, demonstrating that high blood pressure (among other components of metabolic syndrome) was more prevalent in men than in women [39]. Our data may support this for SAH, because men had significantly higher median SBP and DBP values and hypertension than women (Table 1 and Figure 2). However, additional studies are needed to confirm this hypothesis, since there may be other contributing factors. For example, the men in this study were older than the women (Table 1), and the risk of hypertension increases with increased age [41]. On the other hand, women had significantly higher BMI values than men (Table 1), and central obesity plays an important role in the development of NCDs [23].

Our results in women of riverine communities showed that women were more frequently affected by SAH than by altered FBS, based on the 2017 ACC/AHA guidelines [22] (Figure 2). However, the previous AHA and VIGITEL (2016) guidelines [18,42] defined SAH as SBP $\geq 140 \mathrm{mmHg}$ and/or $\mathrm{DPB} \geq 90 \mathrm{mmHg}$ rather than 130 and 80, respectively. Using the latter guidelines, the prevalence of altered FBS in women, 30\%, was higher than the prevalence of hypertension (systolic or diastolic), 22 to $20 \%$, (Fisher's exact test, $p<0.05$ ). Notably, in Amazonian urban populations, SAH showed a higher prevalence in women $[18,33]$. Environmental factors, nutritional factors, and life style factors contribute to the differences in NCD profiles in urban and riverine populations of the Amazon, emphasizing the importance of conducting epidemiological studies.

The most recent data [18] show that diagnosis of SAH have increased by $3.5 \%$ in the last 10 years in Brazilian capitals, with higher prevalence in women and in individuals with a low educational level. Curiously, the northern region currently shows the lowest SAH prevalence in the country [18]. Hypertension is a preventable cause of cardiovascular morbidity and mortality, and blood pressure is a good indicator of risk for CVDs. This parameter is relatively easy to measure, even in remote field research conditions [26], but few studies have investigated blood pressure in Amazonian riverine populations.

Interestingly, the Tapajós River Basin is one of the few locations in the Amazon in which blood pressure has been evaluated, which allowed us to look at tendencies over time. Fillion et al. (2006) [26] reported values of $113.9 \pm 14.6 \mathrm{mmHg}$ for mean SBP and $73.7 \pm 11.0 \mathrm{mmHg}$ for mean DBP in riverine communities in this region. The mean SBP and DBP values in our study were $126.4 \pm 21.5$ and $78.3 \pm 14.1 \mathrm{~mm} \mathrm{Hg}$, respectively, in the 444 participants in the Tapajós River basin, which is higher than those found 10 years ago ( $t$-test; $p<0.0001$ ). In 2006, systolic hypertension (defined as SBP $\geq 140 \mathrm{mmHg}$ ) had a prevalence of $8 \%$ in these populations [26]. Using this definition of SBP, the prevalence would be $24 \%$ (CI: 21.1-27.3) in our study. Our data are in accordance with other data 
showing high prevalence of SAH in Amazonian riverine populations [43]. Thus, NCDs appear to be a chronic problem in this area.

A subgroup composed only of 'presumably healthy' subjects was created to avoid biasing our conclusions by including subjects with NCD diagnosis such as SAH and/or DM (Figure 3). This subgroup excluded participants with a diagnosis or history of chronic diseases such as CVDs, hypertension, or DM, as well as participants with known risk factors, such as those who smoked, drank alcohol, or had drug dependency or chronic treatment with drugs. This analysis allowed us to identify 298 participants who showed altered FBS and/or SAH but who had not been diagnosed or treated. This meant that more than half (58.1\%) of all participants with high FBS and/or hypertension were not aware that these conditions could make them at-risk of NCDs. This suggested that there are many undiagnosed cases in Amazonian riverine populations (Figure 3).

It is essential to analyze genetic susceptibility to NCDs in order to effectively manage and treat these vulnerable populations. This study was the first to analyze the APOE4 genotype as a biomarker of susceptibility to NCDs in riverine populations of the Amazon. The allelic frequency distribution in this population was $0.05,0.77$, and 0.18 for the $\varepsilon 2, \varepsilon 3$, and $\varepsilon 4$ alleles, respectively. This is similar to the distribution described previously in other populations in South America $(0.046,0.767$, and 0.187, respectively) [44]. Carrying the $\varepsilon 4$ allele increases susceptibility to many NCDs, such as diabetes and hypertension [8-10], and to neurodegenerative disorders, such as Alzheimer's disease [11], and it does not seem to be influenced by sex [4,45-47]. This analysis identified 246 individuals (32.2\%; CI: 28.9-35.7) with this risk factor (Figure 4). Moreover, the presence of ApoE4 in addition to hypertension increases the risk of Alzheimer's disease 1.5-fold [48]; in our work, 55.0\% (CI: 48.5-61.3) of $\varepsilon 4$ carriers had hypertension. Preventive strategies are especially important for these individuals in order to reduce the prevalence of NCDs in the Amazon.

The finding that Amazonian riverine population have an APOE4 frequency similar to that of other populations suggests that environmental factors rather than increased genetic susceptibility is responsible for the high prevalence of NCDs.

Traditionally, the isolation of the Amazonian populations has been considered to be a protective factor against CVDs [49]. In addition, the traditional lifestyle in this region with a diet in which fish is the main source of protein (high in omega- 3 fatty acids and low in saturated fats) is protective against CVDs [50]. Unfortunately, Amazonian riverine population currently faces two main problems that are acting as negative modulators: environmental contamination and the nutritional transition.

Both regions in the present work represent anthropogenic contamination of the Amazonian environment. The major small-scale gold-mining area in the Amazon is located in the Tapajós River basin and is responsible for chronic environmental mercury contamination (reviewed by [51]). Mercury is also found naturally in Amazonian soils and is concentrated in the environment by man-made large-scale projects such as dams. One of the largest dams in the world is located in Tucuruí (Figure 1), and human exposure to high levels of mercury was recently demonstrated in riverine population in this area [34]. Mercury is bioaccumulated and biomagnified through the food chain and by piscivorous fish, which are the species that are typically consumed the most by riverine population [52,53]. These fish show the highest levels of contamination [52,53]. A growing body of evidence suggests that mercury exposure can increase the risk of adverse cardiovascular impact in exposed populations [26,54-58]. Indeed, in Tapajós area blood pressure was significantly associated with the total mercury in hair, supporting mercury cardiovascular toxicity [26].

The nutritional transition is a more recent issue in the Amazon. In the last decade, governmental program has increased the purchasing power of individuals at a level that is sufficient to influence the nutritional status of these populations in both positive and negative ways [2]. One program is "Bolsa Familia" which provides an economic incentive for the poorest families to keep their children in school. There has been an increase in carbohydrate-rich, fatty, low-fiber foods in the diet of people in the Tapajós River basin, and an increase in the presence of radios, furniture, etc. in homes has led to more sedentary habits [5]. In other populations around the world, changes like 
these have been associated with increases in chronic diseases such as type 2 diabetes, hypertension, and CVDs [59-63].

Our limited knowledge about the current health status of Amazonian populations makes it difficult to develop efficacious healthcare strategies. The Brazilian National Public Healthcare System, known as the Unified Health System (Sistema Único de Saúde, SUS, in Portuguese), theoretically provides free access to primary, secondary, and tertiary healthcare to citizens [20]. However, the reality is very different for citizens who live in the Amazon. Prevention strategies that are tailored to the different profiles of Amazonian populations are needed to control NCDs and to hopefully reverse the trend towards an even higher prevalence of NCDs. Our results will better assist the development of these preventive strategies and governmental actions for adequate management of NCDs in the Amazon.

\section{Conclusions}

The Amazonian riverine population showed a high prevalence of altered FBS (impaired glucose tolerance or suspected diabetes mellitus) and/or SAH. The prevalence of these conditions were as high as their prevalence in the largest cities in the country (Rio de Janeiro and São Paulo) and were well above the prevalence found in Amazonian urban regions. More than half of the individuals with altered findings had never been diagnosed and were not being treated for their conditions. This could contribute to the finding of an increased mortality rate (up to $28 \%$ in the Northern region of Brazil) due to cardiovascular diseases.

About one-third of the participants had a genetic susceptibility (APOE4) to NCDs, which helps identify high-risk individuals. This prevalence is similar to that in other South American populations, suggesting that additional factors underlie the alterations detected in our study. We hypothesize that environmental contamination and nutritional transitions are two such factors.

Prevention strategies that are tailored to specific Amazonian populations are needed to control and even reverse the high prevalence of NCDs. Our results will help develop such preventive strategies and can help shape appropriate governmental actions to better identify and manage NCDs in the Amazon.

Author Contributions: Conceptualization: G.P.F.A., J.I.A.-L., J.R.S.-M., M.A.-O., B.M.M., R.B.O., J.L.M.d.N. and M.E.C.-L.; Data curation: G.P.F.A., J.I.A.-L., M.A.-O., B.M.M., A.P. and M.E.C.-L.; Formal analysis: G.P.F.A., J.I.A.-L., M.A.-O. and M.E.C.-L.; Funding acquisition: G.P.F.A., J.I.A.-L., R.B.O., J.L.M.d.N. and M.E.C.-L.; Methodology: G.P.F.A., J.R.S.-M., M.A.-O., R.P., B.M.M., A.P. and M.E.C.-L.; Project administration: M.E.C.-L.; Resources, G.P.F.A., J.I.A.-L., B.M.M., J.L.M.d.N. and M.E.C.-L.; Writing-original draft: G.P.F.A. and M.E.C.-L.; Writing—review \& editing: G.P.F.A., J.I.A.-L., J.R.S.-M., M.A.-O., R.P., B.M.M., A.P., R.B.O., J.L.M.d.N. and M.E.C.-L.

Funding: This work was supported by Conselho Nacional de Ciência e Tecnologia em Pesquisa (CNPq, Brazil; grants numbers 467143/2014-5 and 447568/2014-0), Coordenação de Aperfeiçoamento de Pessoal de Nivel Superior (CAPES, Brazil), and Pró-Reitoria de Pesquisa da UFPA (PROPESP, UFPA, Brazil). J.L.M. do Nascimento, M.E. Crespo-López, G.P.F. Arrifano thank CNPq for their researcher fellowships. Also, G.P.F. Arrifano and M.A. Oliveira thank CAPES for their post-doctoral and PhD fellowships, respectively.

Acknowledgments: We thank healthcare agents of the communities for their warmly welcome and essential support to this study. Also, the team of Radio in both areas is sincerely acknowledged for their valuable help.

Conflicts of Interest: The authors declare no conflict of interest. The funders had no role in the design of the study; in the collection, analyses, or interpretation of data; in the writing of the manuscript, or in the decision to publish the results.

\section{References}

1. IBGE. 2016. Available online: http://www.ibge.gov.br/home/estatistica/populacao/estimativa2016/ default.shtm (accessed on 25 July 2018).

2. Muzaka, V. Lessons from Brazil: On the difficulties of building a universal health care system. J. Glob. Health 2017, 7. [CrossRef] [PubMed]

3. Human Development Atlas in Brazil. Brazil 2013. Available online: http://atlasbrasil.org.br/2013/en/ home/ (accessed on 25 July 2018). 
4. Arrifano, G.P.F.; Martin-Doimeadios, R.C.R.; Jimenez-Moreno, M.; Fernandez-Trujillo, S.; Augusto-Oliveira, M.; Souza-Monteiro, J.R.; Macchi, B.M.; Alvarez-Leite, J.; Do Nascimento, J.L.M.; Amador, M.; et al. Genetic susceptibility to neurodegeneration in Amazon: Apolipoprotein E genotyping in vulnerable populations exposed to mercury. Front. Genet. 2018. [CrossRef]

5. Piperata, B.A.; Spence, J.E.; Da-Gloria, P.; Hubbe, M. The nutrition transition in Amazonia: Rapid economic change and its impact on growth and development in Ribeirinhos. Am. J. Phys. Anthropol. 2011, 146, 1-13. [CrossRef] [PubMed]

6. Jacobs, A.; Richtel, M. How Big Business Got Brazil hooked on Junk Food. New York Times, 16 September 2017. Available online: https:/ /www.nytimes.com/interactive/2017/09/16/health/brazil-obesity-nestle.html (accessed on 25 July 2018).

7. World Health Organization. Noncommunicable Diseases. Fact Sheet; WHO: Geneva, Switzerland, 2017; Available online: http:/ / www.who.int/mediacentre/factsheets/fs355/en/ (accessed on 25 July 2018).

8. Freitas, R.G.; Campana, E.M.; Pozzan, R.; Brandao, A.A.; Brandao, A.P.; Magalhaes, M.E.; Silva, D.A. Apoe and ldlr gene polymorphisms and dyslipidemia tracking. Rio de Janeiro study. Arq. Bras. Cardiol. 2015, 104, 468-474. [CrossRef] [PubMed]

9. El-Lebedy, D.; Raslan, H.M.; Mohammed, A.M. Apolipoprotein e gene polymorphism and risk of type 2 diabetes and cardiovascular disease. Cardiovasc. Diabetol. 2016, 15. [CrossRef]

10. Midorikawa, K.; Soukaloun, D.; Akkhavong, K.; Southivong, B.; Rattanavong, O.; Sengkhygnavong, V.; Pyaluanglath, A.; Sayasithsena, S.; Nakamura, S.; Midorikawa, Y.; et al. Apoe genotype in the ethnic majority and minority groups of laos and the implications for non-communicable diseases. PLoS ONE 2016, 11. [CrossRef] [PubMed]

11. Arrifano, G.P.F.; de Oliveira, M.A.; Souza-Monteiro, J.R.; Paraense, R.O.; Ribeiro-Dos-Santos, A.; Vieira, J.; Silva, A.; Macchi, B.M.; do Nascimento, J.L.M.; Burbano, R.M.R.; et al. Role for apolipoprotein e in neurodegeneration and mercury intoxication. Front. Biosci. 2018, 10, 229-241.

12. Mahley, R.W. Apolipoprotein e: From cardiovascular disease to neurodegenerative disorders. J. Mol. Med. 2016, 94, 739-746. [CrossRef] [PubMed]

13. Alharbi, K.K.; Khan, I.A.; Syed, R. Association of apolipoprotein e polymorphism with type 2 diabetes mellitus in a saudi population. DNA Cell Biol. 2014, 33, 637-641. [CrossRef] [PubMed]

14. Zhu, S.; Wang, Z.; Wu, X.; Shu, Y.; Lu, D. Apolipoprotein e polymorphism is associated with lower extremity deep venous thrombosis: Color-flow doppler ultrasound evaluation. Lipids Health Dis. 2014, 13. [CrossRef] [PubMed]

15. Li, H.; Dhanasekaran, P.; Alexander, E.T.; Rader, D.J.; Phillips, M.C.; Lund-Katz, S. Molecular mechanisms responsible for the differential effects of apoe3 and apoe4 on plasma lipoprotein-cholesterol levels. Arterioscler. Thromb. Vasc. Biol. 2013, 33, 687-693. [CrossRef] [PubMed]

16. Zhao, N.; Liu, C.C.; Van Ingelgom, A.J.; Martens, Y.A.; Linares, C.; Knight, J.A.; Painter, M.M.; Sullivan, P.M.; $\mathrm{Bu}, \mathrm{G}$. Apolipoprotein e4 impairs neuronal insulin signaling by trapping insulin receptor in the endosomes. Neuron 2017, 96, 115-129. [CrossRef] [PubMed]

17. World Health Organization (WHO). Noncommunicable Diseases (NCD) Country Profiles; WHO: Geneva, Switzerland, 2014; Available online: http:/ /apps.who.int/iris/bitstream/10665/128038/1/9789241507509_ eng.pdf (accessed on 25 July 2018).

18. Vigitel. Vigitel Brasil 2016 Vigilância de Fatores de Risco e Proteção Para Doenças Crônicas Por Inquérito Telefônico. Brazil: Ministério da Saúde; 2016. Available online: http:/ / portalsaude.saude.gov.br/index.php/ o-ministerio/principal/leia-mais-o-ministerio/673-secretaria-svs/vigilancia-de-a-a-z/doencas-cronicasnao-transmissiveis/12-doencas-cronicas-nao-transmissiveis/14128-vigitel-2006-a-2013 (accessed on 25 July 2018).

19. BRASIL. A Vigilância, o Controle e a Prevenção das Doenças Crônicas Não-Transmissíveis: Dcnt No Contexto do Sistema Único de Saúde Brasileiro; Ministério Da Saúde/Opas/Oms: Brasilia, Brazil, 2005.

20. Coutinho, W.F.; Silva Junior, W.S. Diabetes care in brazil. Ann. Glob. Health 2015, 81, 735-741. [CrossRef] [PubMed]

21. Association, A.D. 2. Classification and diagnosis of diabetes. Diabetes Care 2016, 39 (Suppl. 1), S13-S22. 
22. Whelton, P.K.; Carey, R.M.; Aronow, W.S.; Casey, D.E.J.; Collins, K.J.; Dennison Himmelfarb, C.; DePalma, S.M.; Gidding, S.; Jamerson, K.A.; Jones, D.W.; et al. 2017 ACC/AHA/AAPA/ABC/ACPM/ AGS/APHA/ASH/ASPC/NMA/PCNA guideline for the prevention, detection, evaluation, and management of high blood pressure in adults: A report of the american college of cardiology/American heart association task force on clinical practice guidelines. J. Am. Coll. Cardiol. 2017. [CrossRef]

23. Schmidt, M.I.; Duncan, B.B.; Azevedo e Silva, G.; Menezes, A.M.; Monteiro, C.A.; Barreto, S.M.; Chor, D.; Menezes, P.R. Chronic non-communicable diseases in Brazil: Burden and current challenges. Lancet 2011, 377, 1949-1961. [CrossRef]

24. Baena, C.P. Doença Cardiovascular: Tendência de Mortalidade No Brasil e Prevenção Global; Pontifical Catholic University of Paraná (PUCPR): Curitiba, Brazil, 2013.

25. Leino, T.; Lodenius, M. Human hair mercury levels in Tucurui area, State of Para, Brazil. Sci. Total Environ. 1995, 175, 119-125. [CrossRef]

26. Fillion, M.; Mergler, D.; Sousa Passos, C.J.; Larribe, F.; Lemire, M.; Guimaraes, J.R. A preliminary study of mercury exposure and blood pressure in the Brazilian Amazon. Environ. Health Glob. Access Sci. Source 2006, 5. [CrossRef] [PubMed]

27. Pinheiro, M.C.; Crespo-Lopez, M.E.; Vieira, J.L.; Oikawa, T.; Guimaraes, G.A.; Araujo, C.C.; Amoras, W.W.; Ribeiro, D.R.; Herculano, A.M.; do Nascimento, J.L.; et al. Mercury pollution and childhood in Amazon riverside villages. Environ. Int. 2007, 33, 56-61. [CrossRef] [PubMed]

28. Pinheiro, M.C.; Macchi, B.M.; Vieira, J.L.; Oikawa, T.; Amoras, W.W.; Guimaraes, G.A.; Costa, C.A.; Crespo-Lopez, M.E.; Herculano, A.M.; Silveira, L.C.; et al. Mercury exposure and antioxidant defenses in women: A comparative study in the Amazon. Environ. Res. 2008, 107, 53-59. [CrossRef] [PubMed]

29. Pinheiro, M.C.; Oikawa, T.; Vieira, J.L.; Gomes, M.S.; Guimaraes, G.A.; Crespo-Lopez, M.E.; Muller, R.C.; Amoras, W.W.; Ribeiro, D.R.; Rodrigues, A.R.; et al. Comparative study of human exposure to mercury in riverside communities in the Amazon region. Braz. J. Med. Biol. Res. 2006, 39, 411-414. [CrossRef] [PubMed]

30. Crespo-Lopez, M.E.; Macedo, G.L.; Arrifano, G.P.; Pinheiro Mda, C.; do Nascimento, J.L.; Herculano, A.M. Genotoxicity of mercury: Contributing for the analysis of Amazonian populations. Environ. Int. 2011, 37, 136-141. [CrossRef] [PubMed]

31. Khoury, E.D.; Souza Gda, S.; Silveira, L.C.; Costa, C.A.; Araujo, A.A.; Pinheiro Mda, C. Neurological manifestations in riverine populations from areas exposed to mercury in the Brazilian Amazon. Cad. Saude Publ. 2013, 29, 2307-2318. [CrossRef]

32. Faial, K.; Deus, R.; Deus, S.; Neves, R.; Jesus, I.; Santos, E.; Alves, C.N.; Brasil, D. Mercury levels assessment in hair of riverside inhabitants of the Tapajos river, Para State, Amazon, Brazil: Fish consumption as a possible route of exposure. J. Trace Elem. Med. Biol. 2015, 30, 66-76. [CrossRef] [PubMed]

33. Franca, S.L.; Lima, S.S.; Vieira, J.R. Metabolic syndrome and associated factors in adults of the Amazon region. PLOS ONE 2016, 11. [CrossRef] [PubMed]

34. Arrifano, G.P.F.; Martin-Doimeadios, R.C.R.; Jimenez-Moreno, M.; Ramirez-Mateos, V.; da Silva, N.F.S.; Souza-Monteiro, J.R.; Augusto-Oliveira, M.; Paraense, R.S.O.; Macchi, B.M.; do Nascimento, J.L.M.; et al. Large-scale projects in the Amazon and human exposure to mercury: The case-study of the tucurui dam. Ecotoxicol. Environ.Saf. 2018, 147, 299-305. [CrossRef] [PubMed]

35. Valentini, J.; Passos, C.J.S.; Garcia, S.C.; Davidson, R.; Lucotte, M.; Mertens, F.; Romana, C.; Valadão, L.M.; Charão, M.F.; Baierle, M.; et al. Blood antioxidant nutrients in riparian villagers of the Brazilian Amazon: Its associations with wet/dry seasons and modulation by sociodemographic determinants. Cad. Saúde Colet. 2016, 24, 21-31. [CrossRef]

36. Krewer, C.C.; Ribeiro, E.E.; Ribeiro, E.A.; Moresco, R.N.; da Rocha, M.I.; Montagner, G.F.; Machado, M.M.; Viegas, K.; Brito, E.; da Cruz, I.B. Habitual intake of guarana and metabolic morbidities: An epidemiological study of an elderly Amazonian population. Phytother. Res. 2011, 25, 1367-1374.

37. Gomes, R.; Nascimento, E.F.; Araujo, F.C. Why do men use health services less than women? Explanations by men with low versus higher education. Cad. Saude Publ. 2007, 23, 565-574. [CrossRef]

38. Anish, T.S.; Shahulhameed, S.; Vijayakumar, K.; Joy, T.M.; Sreelakshmi, P.R.; Kuriakose, A. Gender difference in blood pressure, blood sugar, and cholesterol in young adults with comparable routine physical exertion. J. Fam. Med. Prim. Care 2013, 2, 200-203. [CrossRef] [PubMed] 
39. Chen, K.W.; Meng, F.C.; Shih, Y.L.; Su, F.Y.; Lin, Y.P.; Lin, F.; Lin, J.W.; Chang, W.K.; Lee, C.J.; Li, Y.H.; et al. Sex-specific association between metabolic abnormalities and elevated alanine aminotransferase levels in a military cohort: The chief study. Int. J. Environ. Res. Public Health 2018, 15. [CrossRef] [PubMed]

40. Ahmed, S.M.; Hadi, A.; Razzaque, A.; Ashraf, A.; Juvekar, S.; Ng, N.; Kanungsukkasem, U.; Soonthornthada, K.; Van Minh, H.; Huu Bich, T. Clustering of chronic non-communicable disease risk factors among selected Asian populations: Levels and determinants. Glob. Health Action 2009, 2. [CrossRef] [PubMed]

41. Chen, H.; Dai, J. BMI better explains hypertension in Chinese senior adults and the relationship declines with age. Aging Clin. Exp. Res. 2015, 27, 271-279. [CrossRef] [PubMed]

42. Gabb, G.M.; Mangoni, A.A.; Anderson, C.S.; Cowley, D.; Dowden, J.S.; Golledge, J.; Hankey, G.J.; Howes, F.S.; Leckie, L.; Perkovic, V.; et al. Guideline for the diagnosis and management of hypertension in adults 2016. Med. J. Aust. 2016, 205, 85-89. [CrossRef] [PubMed]

43. Oliveira, B.F.; Mourao Dde, S.; Gomes, N.; Costa, J.M.; Souza, A.V.; Bastos, W.R.; Fonseca Mde, F.; Mariani, C.F.; Abbad, G.; Hacon, S.S. Prevalence of arterial hypertension in communities along the madeira river, western Brazilian Amazon. Cad. Saude Publ. 2013, 29, 1617-1630. [CrossRef]

44. Singh, P.P.; Singh, M.; Mastana, S.S. Apoe distribution in world populations with new data from India and the UK. Ann. Hum. Biol. 2006, 33, 279-308. [CrossRef] [PubMed]

45. De Franca, E.; Alves, J.G.; Hutz, M.H. Apolipoprotein e polymorphism and its association with serum lipid levels in Brazilian children. Hum. Biol. 2004, 76, 267-275. [CrossRef] [PubMed]

46. Souza, D.R.; Nakachima, L.; Biagioni, R.B.; Nakazone, M.A.; Pinhel, M.A.; Trindade, D.M.; Mafra, V.T.; Tacito, L.H.; Martin, J.F.; Pinheiro Junior, S.; et al. Relevance of apolipoprotein e4 for the lipid profile of brazilian patients with coronary artery disease. Braz. J. Med. Biol. Res. 2007, 40, 189-197. [CrossRef] [PubMed]

47. Ferreira, D.C.; Costa, T.F.; Aguiar, S.L.; Marques, A.R.; Ramos, S.A.; Gomes, K.B.; Alvarez-Leite, J.I. Association of apoliprotein e polymorphisms and metabolic syndrome in subjects with extreme obesity. Clin. Chim. Acta 2011, 412, 1559-1562. [CrossRef] [PubMed]

48. Sery, O.; Hlinecka, L.; Balcar, V.J.; Janout, V.; Povova, J. Diabetes, hypertension and stroke-Does alzheimer protect you? Neuro Endocrinol. Lett. 2014, 35, 691-696. [PubMed]

49. Pavan, L.; Casiglia, E.; Braga, L.M.; Winnicki, M.; Puato, M.; Pauletto, P.; Pessina, A.C. Effects of a traditional lifestyle on the cardiovascular risk profile: The amondava population of the Brazilian Amazon. Comparison with matched African, Italian and Polish populations. J. Hypertens. 1999, 17, 749-756. [CrossRef] [PubMed]

50. Kromhout, D.; Yasuda, S.; Geleijnse, J.M.; Shimokawa, H. Fish oil and omega-3 fatty acids in cardiovascular disease: Do they really work? Eur. Heart J. 2012, 33, 436-443. [CrossRef] [PubMed]

51. Berzas Nevado, J.J.; Rodriguez Martin-Doimeadios, R.C.; Guzman Bernardo, F.J.; Jimenez Moreno, M.; Herculano, A.M.; do Nascimento, J.L.; Crespo-Lopez, M.E. Mercury in the Tapajos river basin, Brazilian Amazon: A review. Environ. Int. 2010, 36, 593-608. [CrossRef] [PubMed]

52. Rodriguez Martin-Doimeadios, R.C.; Berzas Nevado, J.J.; Guzman Bernardo, F.J.; Jimenez Moreno, M.; Arrifano, G.P.; Herculano, A.M.; do Nascimento, J.L.; Crespo-Lopez, M.E. Comparative study of mercury speciation in commercial fishes of the Brazilian Amazon. Environ.Sci. Pollut. Res. Int. 2014, 21, 7466-7479. [CrossRef] [PubMed]

53. Isaac, V.J.; Almeida, M.C.; Giarrizzo, T.; Deus, C.P.; Vale, R.; Klein, G.; Begossi, A. Food consumption as an indicator of the conservation of natural resources in riverine communities of the Brazilian Amazon. An. Acad. Bras. Cienc. 2015, 87, 2229-2242. [CrossRef] [PubMed]

54. Genchi, G.; Sinicropi, M.S.; Carocci, A.; Lauria, G.; Catalano, A. Mercury exposure and heart diseases. Int. J. Environ. Res. Public Health 2017, 14. [CrossRef] [PubMed]

55. Houston, M.C. Role of mercury toxicity in hypertension, cardiovascular disease, and stroke. J. Clin. Hypertens. 2011, 13, 621-627. [CrossRef] [PubMed]

56. Houston, M. The role of mercury in cardiovascular disease. J. Cardiovasc. Dis. Diagn. 2014, 2. [CrossRef]

57. Valera, B.; Dewailly, E.; Poirier, P. Cardiac autonomic activity and blood pressure among nunavik inuit adults exposed to environmental mercury: A cross-sectional study. Environ. Health Glob. Access Sci. Source 2008, 7. [CrossRef] [PubMed] 
58. Arrifano, G.P.F.; Martin-Doimeadios, R.C.R.; Jimenez-Moreno, M.; Augusto-Oliveira, M.; Souza-Monteiro, J.R.; Paraense, R.; Machado, C.R.; Farina, M.; Macchi, B.; do Nascimento, J.L.M.; et al. Assessing mercury intoxication in isolated/remote populations: Increased S100B mRNA in blood in exposed riverine inhabitants of the Amazon. Neurotoxicology 2018, 68, 151-158. [CrossRef] [PubMed]

59. Gugelmin, S.A.; Santos, R.V. Human ecology and nutritional anthropometry of adult xavante Indians in mato grosso, Brazil. Cad. Saude Publ. 2001, 17, 313-322. [CrossRef]

60. Lindgarde, F.; Ercilla, M.B.; Correa, L.R.; Ahren, B. Body adiposity, insulin, and leptin in subgroups of peruvian Amerindians. High Altit. Med. Biol. 2004, 5, 27-31. [CrossRef] [PubMed]

61. Benefice, E.; Lopez, R.; Monroy, S.L.; Rodriguez, S. Fatness and overweight in women and children from riverine amerindian communities of the Beni River (Bolivian Amazon). Am. J. Hum. Biol. 2007, 19, 61-73. [CrossRef] [PubMed]

62. Blackwell, A.D.; Pryor, G., 3rd; Pozo, J.; Tiwia, W.; Sugiyama, L.S. Growth and market integration in Amazonia: A comparison of growth indicators between shuar, shiwiar, and nonindigenous school children. Am. J. Hum. Biol. 2009, 21, 161-171. [CrossRef] [PubMed]

63. Welch, J.R.; Ferreira, A.A.; Santos, R.V.; Gugelmin, S.A.; Werneck, G.; Coimbra, C.E.A. Nutrition transition, socioeconomic differentiation, and gender among adult xavante Indians, Brazilian Amazon. Hum. Ecol. 2009, 37, 13-26. [CrossRef]

(C) 2018 by the authors. Licensee MDPI, Basel, Switzerland. This article is an open access article distributed under the terms and conditions of the Creative Commons Attribution (CC BY) license (http:/ / creativecommons.org/licenses/by/4.0/). 